\title{
咀嚼圧力分布に基づく食品テクスチャセンシング
}

\author{
東 森充*1 金子真*1 福 田修*2
}

\section{Food Texture Sensing based on Mastication Pressure Distribution}

\author{
Mitsuru Higashimori*1, Makoto Kaneko*1 and Osamu Fukuda*2
}

\begin{abstract}
This paper proposes a sensing method to evaluate the food texture which is associated to human's impression in mastication. Nursing-care jelly foods, which can be masticated by tongue, are treated. An experimental mastication model are utilized to measure the pressure distribution response of a food in the compression and the fracture. Based on the texture analysis for image, feature values of the pressure distribution are extracted. Testing known foods whose impression levels are obtained by the sensory test, the regression equation modeling the relationship between the feature values and the impression level is derived. By giving the pressure distribution of an unknown food to this model, its impression level can be estimated. Experimental results show that impression levels of three different jelly foods are appropriately estimated.
\end{abstract}

Key Words: Food Texture Sensing, Mastication Model, Texture Analysis, Pressure Distribution

\section{1.は じめに}

高齢者や障害者向けに，舌と口蓋を使って咀嚼すること（以 下，舌式咀嚼と呼ぶ）が可能な水分㧍よび栄養補給用ゼリーが 開発されている。このような介護食ゼリーに扔いては, 咀嚼・嚥 下の安全性と美味しさが高次元で両立することが望まれる。美 味しさは, 味や香りといった食品の化学的性質のみでなく, 咀 嚼・舆下過程に扔ける食品の物理的性質に起因するテクスチャ （舌触り，口溶け，喉越しなど）にも強く依存する [1]. 食品のテ クスチャは, 機械的特性（かたさ，もろさ，粘り，など）と幾何 学特性（滑らかさ, ざらつき, 粒子の大きさと形, など）に大別 され [2], ヒトが直接判断する官能試験によって評価される。機 械的特性に関しては, 物理的測定によって食品テクスチャを定 量的に評価する手法の開発が試みられており, 食品圧縮試験か ら得られる力応答を用いたテクスチャプロファイル法 [3] が確立 され，テクスチュロメーター[4]，テクスチャーアナライザー [5] 等の測定機器が実用化されている。 これに対して, 幾何学的特 性に関する研究として, Ishihara らは, 咀嚼による食品の形態 変化を評価するために咀嚼後の食品粒度を計測している $[6]$. 今 井らは, 口腔内で食品粒子を認識する際の最小粒度および粒子 の大きさの識別程度を官能試験によって評価している [7]. 神山

原稿受付 2012 年 12 月 5 日

${ }^{* 1}$ 大阪大学大学院工学研究科

$* 2$ 独立行政法人産業技術総合研究所生産計測技術研究センター

${ }^{* 1}$ Graduated School of Engineering, Osaka University

${ }^{* 2}$ National Institute of Advanced Industrial Science and Technology, Measurement Solution Research Center

ロ 本論文は有用性で評価されました。
は, 口腔内で咀嚼動作中に生じる圧力分布を計測し, 食品水分 活性值との関係について考察している $[8]$. また, 羊美, 食パン, クラッカー, 生ニンジンの圧縮過程に抢ける圧力分布の相違を 考察している [9]. 以上のように, 幾何学的特性の物理的計測を 試みた研究例は存在するものの, ヒトが咀嚼時に受ける纎細な 印象と関連付けて食品テクスチャを評価する手法は確立されて いないのが現状である。

以上のような背景の下, 本研究では, 舌式咀嚼と介護食ゼリー を対象として取り上げ，幾何学的特性に強く依存した食品テク スチャを物理的測定によって客観的・数值的に評価する手法を構 築することを目的とする，ヒトは舌式咀嚼する際に，食品破断 中の形態変化と力応答を同時に感知し, 何らかの印象を受けて 食品テクスチャを評価している. 本研究ではこの基本原理を工 学的に再現し, 咀嚼実験モデルで得られる圧力分布応答に基づ く食品テクスチャセンシング手法の基本コンセプトを提案する. 提案する食品テクスチャセンシング手法は, 圧力分布センシ ングとテクスチャ解析から構成される，圧力分布センシングで は，ヒトの舌式咀嚼動作をモデル化した咀嚼実験モデルを用い て, 食品圧縮破断時の圧力分布応答を取得する。テクスチャ解 析では，ヒトの官能評価に基づく印象レベルと圧力分布応答と の関倸をモデル化し，印象レベルの推定式を導出する. 本論文 では，上記のような基本コンセプトを確認するために，破断中 の舌触りが明確に異なる 3 種類のゼリー (寒天製, ジェランガ ム製，カラギナン製）を基準食品として取り上げる。はじめに, 3 種類の基準食品について咀嚼実験モデルで得られる圧力分布 応答を示し，同時に計測している力応答の結果と合わせてどの ような違いが見られるかを確認する。続いて, テクスチャ解析 


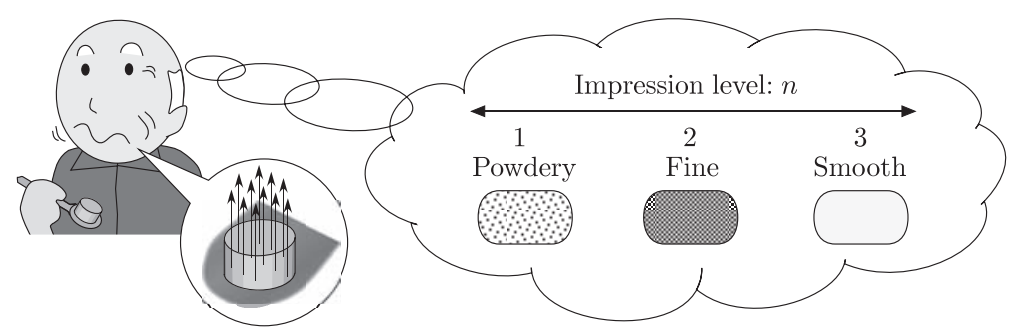

(a) Food texture based on geometrical characteristics in mastication

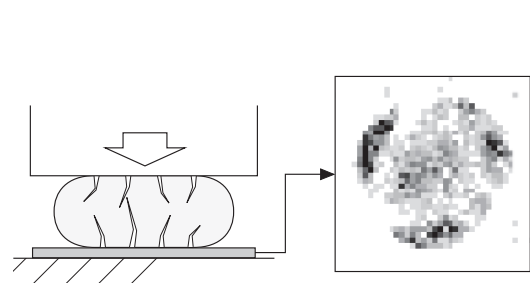

(b) Measuring pressure distribution in experimental mastication model

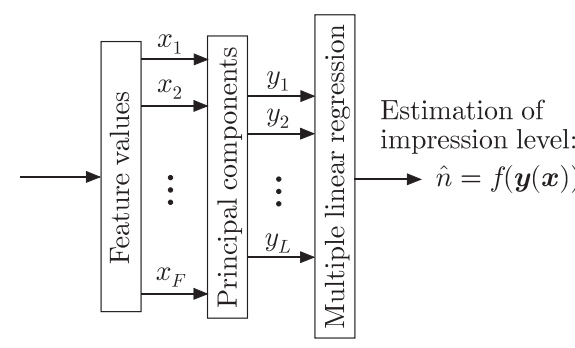

(c) Modeling relationshio between pressure distribution and impressionlevel

Fig. 1 Outline of the proposed method for food texture sensing

により，各食品の圧力分布応答と印象レベルとの関係をモデル 化する。ここでは，まず，空間濃度レベル依存法により圧力分 布応答データの特徴量ベクトルを算出する. 次に, 特徵量ベク トルから主成分ベクトルを算出し，この主成分ベクトルを説明 変数, 印象レベルを目的変数とした重回帰モデルを作成して印 象レベルの推定式を導出する。この推定式から得られた印象レ ベルと実際の印象レベルを比較することにより, 提案手法の有 効性を示す。さらに, 未知食品の印象レベルを推定する手法を 整理し, これらの食品の印象レベルが適切に推定できることを 示す.

本論文の構成は, 以下のとおりである，第 2 章では，提案す る食品テクスチャセンシングの概要を示す。第 3 章では, 咀嚼 実験モデルと圧力分布応答センシングの結果を示す。第 4 章で は, テクスチャ解析による食品テクスチャのモデリングについ て示す. 最後に第 5 章で, 本研究をまとめる.

\section{2. 食品テクスチャセンシングの概要}

人工的な咀嚼実験モデルによって得ることができる実験デー 夕から, 食品テクスチャ（ヒトがその食品を咀嚼した際に感じる 印象）を客観的かつ定量的に推定する手法を提案する. Fig. 1 に, 提案手法の概要を示す。ここでは, 舌式咀嚼可能な食品と して, 介護食ゼリーを対象とする。準備として, ヒトによる官 能評価ずみの試験食品を複数用意し, これらを, 評価軸を構成 するための基準食品と定義する. Fig. 1 (a) に示すように, 幾何 学的特性に基づく食品テクスチャの評価指標として, 印象レべ ル $n$ （例えば, 1 : 粒状, 2 : きめ細かい, $3:$ 滑らか, など）を 設定しておく。これらの基準食品に対して, 以下の手順によっ て実験計測データから印象レベルを推定するためのモデル式を 獲得する。

咀嚼実験モデルを用いた圧力分布応答のセンシング : 舌式咀嚼 を人工的に再現するために, Fig. 1 (b) に示すような咀嚼実験モ
デルを構築する。 ヒトは, 舌式咀嚼において, 食品破断中の形 態変化と力応答を同時に感知している。この基本原理に基づい て, 咀嚼実験モデルは 2 枚の圧縮用プレートと圧力分布センサ から構成されており, 食品を圧縮破断する過程の圧力分布応答 を計測する。この実験モデルによって，印象レベルが異なる基 準食品の圧力分布応答を収集する.

テクスチャ解析による圧力分布応答と印象レベルのモデリング :

Fig. 1 (c) に示すように, 圧力分布応答と印象レベルとの関係を モデル化する. はじめに, 圧力分布応答データに画像テクスチャ 解析手法を適用し, 空間濃度レベル依存法 [10]により求められ る特徵量べクトル $\boldsymbol{x}$ を算出する。次に, これらの特徴量に対す る主成分ベクトル $\boldsymbol{y}$ を算出する. 最後に, 重回帰分析を行い, 主成分ベクトル $\boldsymbol{y}$ と印象レベル $n$ の関係を表す重回帰モデルを 作成することによって, 印象レベルの推定式 $\hat{n}=f(\boldsymbol{y}(\boldsymbol{x}))$ を導 出する. 得られた印象レベルの推定式を用いることにより, 未 知食品の印象レベルを, 咀嚼実験モデルにおける圧力分布応答 から推定することができる。

上記手順の詳細を, 検証結果と合わせて第 3 章, 第 4 章に 示す.

\section{3. 咀嚼実験モデルを用いた圧力分布センシング}

\section{1 咀嚼実験モデル}

Fig. 2 (a) に, 実験システムの概要を示す. 2 枚の圧縮プレー トのうち, 下側のプレートは土台に固定し, 上側のプレートは $\mathrm{PC}$ によって制御可能なリニアスライダによって駆動する.こ こでは, 速度 $2[\mathrm{~mm} / \mathrm{s}]$ の下降動作によって試験食品を圧縮破

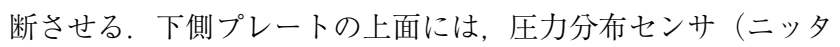
株式会社製：測定範囲 $44 \times 44[\mathrm{~mm}]$, 空間分解能 $1[\mathrm{~mm}]$, 時 間分解能 $10[\mathrm{~ms}]$ ）を設置し, 食品が圧縮破断する際の圧力分布 を時系列データとして記録する. また, リニアスライダと上側 プレート間にロードセルを設置し, 圧縮時の力応答も同時に取 


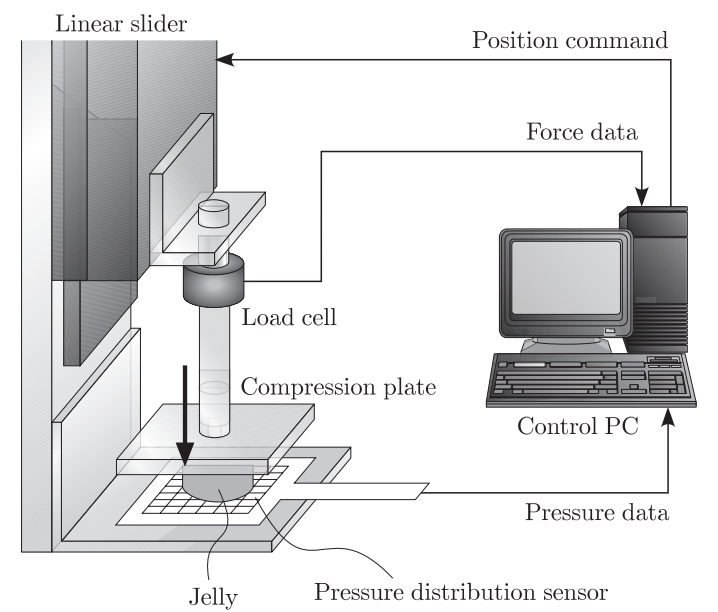

(a)

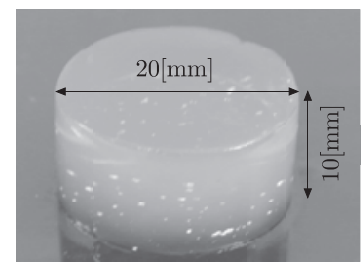

(b)

Fig. 2 Experimental system

得する.

今回, 基準食品として, 幾何学的な食感が明確に異なる 3 種 類のゼリーを使用し，それぞれ印象レベルを $n=1$ (寒天製), $n=2$ (ジェランガム製),$n=3$ (カラギナン製) とする。 な 押, 舌式咀嚼中の舌触りについて, $n=1$ から $n=3$ に向け て滑らかな印象が強くなる. Fig. 2 (b) は, $n=1$ のゼリーで ある. すべてのゼリーは, 直径 $20[\mathrm{~mm}]$, 高さ $10[\mathrm{~mm}]$ の円柱 形としている. 印象レベル $n=1$ のゼリー 11 個, $n=2$ のゼ リー 12 個, $n=3$ のゼリー 11 個の合計 34 個に対して, 咀嚼 実験モデルにおける圧力分布応答を取得する.

\section{2 圧力分布応答センシング}

Fig. 3 に，印象レベル $n=1$ のゼリーに対する実験結果と して, 上側プレートの下降変位とロードセルから得た力応答を 示す，プレートがゼリーを圧縮するにつれ，力応答は上昇する， その後, $t=2.3[\mathrm{~s}]$ でゼリーが破断し始め, 力応答がいったん 下降する，圧縮開始から破断開始直前までの間を圧縮フェーズ とする，引き続き，ゼリーは破断しながら圧縮され続けるため， プレートが停止するまで力応答は再び上昇する。ゼリーの破断 開始からプレート停止までの間を破断フェーズとする. Fig. 4 に, $n=1$ のゼリーを圧縮破断させた際の様子を示す.

一連の圧縮破断操作中に圧力分布センサから得られた圧力值を, $3 \sim 80[\mathrm{kPa}]$ の範囲で $4.8[\mathrm{kPa}]$ ごとに 16 分割し, それぞれ 0 15 の圧力レベル值に変換する. このように変換された圧力分布 応答データを, $N=16$ 段階の濃度レベルを持つ $44 \times 44$ [pixel] の画像情報のフレーム群として取り扱う. Fig. 5 は圧力分布応 答を示す画像の中から, 特徴的なフレーム（左から, 初期状態 直後, 圧縮フェーズ中, 破断フェーズ中）を並べたものである.

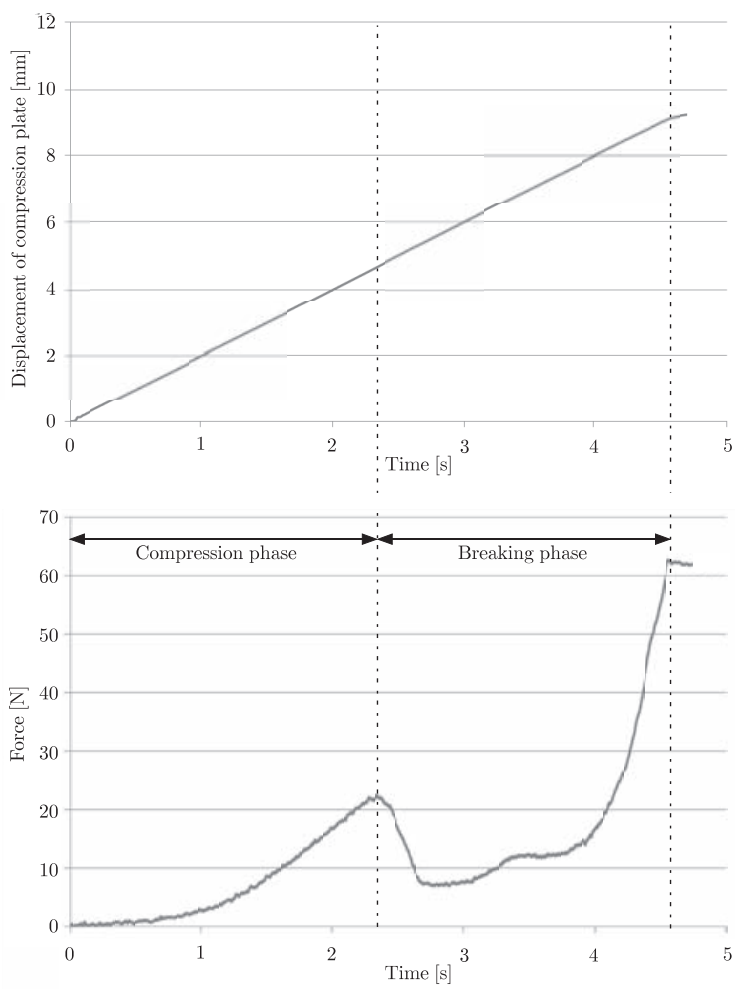

Fig. 3 An example of experimental result in a jelly with $n=1$

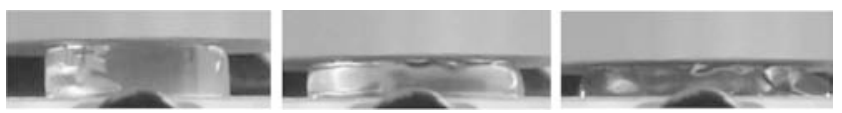

Fig. 4 Compression test in a jelly with $n=1$

ここで, Fig. 5 (a) は $n=1$, (b) は $n=2, \quad(\mathrm{c})$ は $n=3$ の ゼリーの圧力分布である。 各画像において，ピクセル色が濃く なるほど，そのピクセル位置における圧力值が高いことを示し ている. Fig. 5(a)〜(c) のそれぞれに拈いて，左から 1 2 枚目 にかけて圧力がゼリ一底面形状である円状を象りながら上昇し ていくことが分かる，その後，ゼリーは破断し，左から 3 枚目 では破断中のゼリーの幾何学的および力学的状態の違いが確認 できる. Fig. 5 (a)〜 (c) を比較すると, (a) $n=1$ のゼリーの 圧力分布は, (b) $n=2$ 拉よび (c) $n=3$ のゼリーの分布と明 確な違いがある.一方で, (b) $n=2$ と (c) $n=3$ については, 確実に区別可能なほどの分布の違いを目視で定義することは難 しい.

Fig. 6 (a) は，ロードセルから得られた力応答を示しており， 印象レベルに応じて色分けしている. Fig. 6 (a) から， $n=1$ のゼリーの力応答を残りの 2 種類のゼリーの応答と区別するこ とは容易であるが, $n=2$ と $n=3$ のゼリーの一部について は両者を力応答から区別することが困難であることが分かる． Fig. 6 (b) は, $n=2$ と $n=3$ の力応答について, 特に区別し にくいものを抽出したものである.このように, 力応答の波形 が似ている $n=2$ と $n=3$ のゼリーについては, 従来のテク スチャプロファイル法 [3]によって, 食品素材の違い拉よびそれ らの幾何学的特性に基づく食品テクスチャの違いを評価するこ 

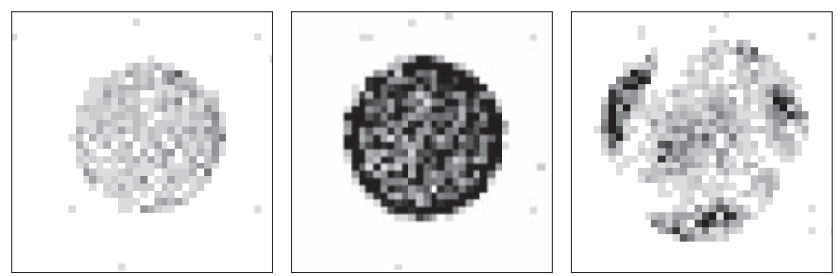

(a) $n=1$ (Agar)
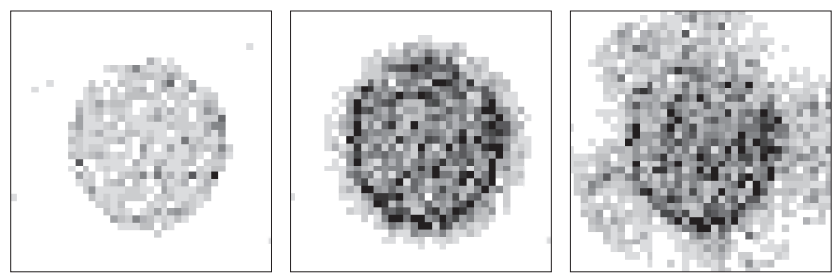

(b) $n=2$ (Gellan gum)
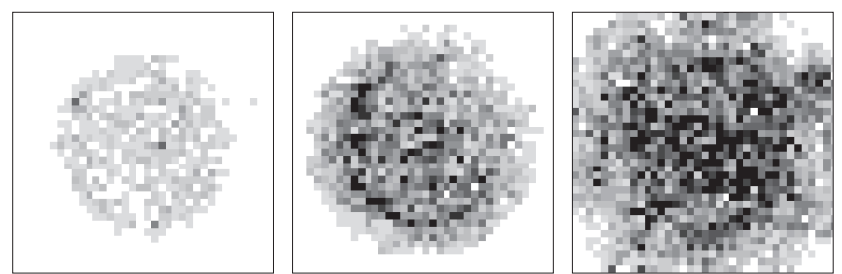

(c) $n=3$ (Carrageenan)

Fig. 5 Pressure distribution response

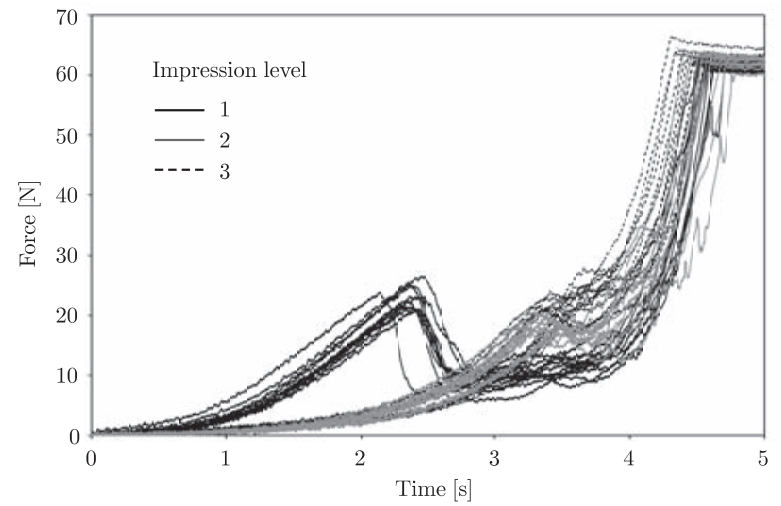

(a)

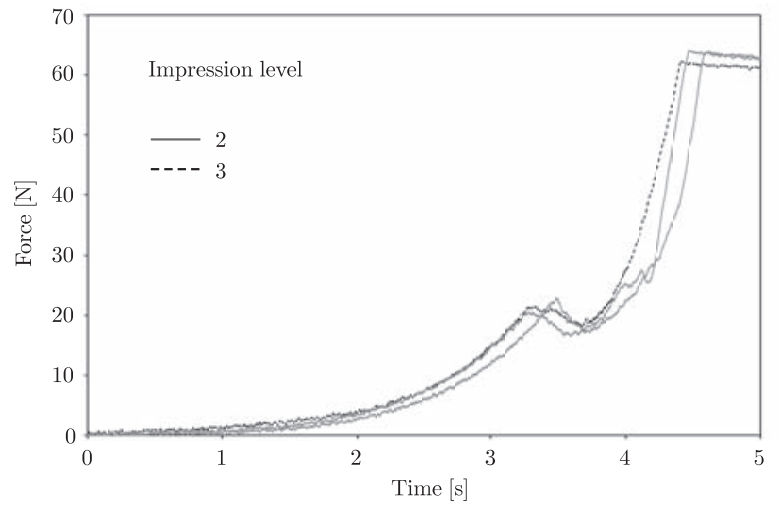

(b)

Fig. 6 Force response
とが困難であることに留意されたい

\section{4. テクスチャ解析による圧力分布応答と印象レベルのモ デリング}

\section{1 圧力分布応答の特徵量算出}

ヒトが舌式咀嚼において食品破断中に感じる印象に着目し, 破 断フェーズの圧力分布応答に対応したフレームのみを解析対象と する，空間濃度レベル依存法 [10]を用いて，画像情報の各フレー ムについてテクスチャ特徵量を算出する。 この手法では, テクス チャ特徵量として, 濃度分布の一様性, 複雑さなどを表す統計量 を算出する，まず，画像情報から濃度共起行列を算出する，濃度 共起行列とは, 画像内に㧍けるピクセル間の濃度関係を表す行 列である. $g(x, y)$ をピクセル $(x, y)$ の濃度レベル, $d, \theta$ をそれ ぞれ走査距離, 走査方向とする. 画像内に打いて, 相対的な位置 関係が $(d, \theta)$ で与えられるピクセル対 $\left(x_{1}, y_{1}\right)$ および $\left(x_{2}, y_{2}\right)$ について，濃度対が $g\left(x_{1}, y_{1}\right)=p$ 抢よび $g\left(x_{2}, y_{2}\right)=q$ である とする．ただし， $p=\{0,1, \ldots, N-1\}, q=\{0,1, \ldots, N-1\}$, $N$ は濃度レベル数である。 このとき, 濃度共起行列 $\boldsymbol{S}_{(d, \theta)}$ の 第 $(p, q)$ 要素をカウントアップする. 画像内の全ピクセルに対 して, $(d, \theta)$ に関する走査を行うことにより, 濃度対 $(p, q)$ の 存在頻度を示す濃度共起行列 $\boldsymbol{S}_{(d, \theta)} \in \Re^{N \times N}$ を決定する。こ こでは, 各フレームについて, $d=1,2,4,8,16$ [pixel], $\theta$ $=0,45,90,135[\mathrm{deg}]$ を組み合わせた計 20 とおりの濃度共起 行列 $\boldsymbol{S}_{(d, \theta)}$ を算出する。 ここで, $\boldsymbol{S}_{(d, \theta)}$ の各要素 $S_{(d, \theta)}(p, q)$ を, 次式で表される確率值 $P_{(d, \theta)}(p, q)$ に変換する。

$$
P_{(d, \theta)}(p, q)=\frac{S_{(d, \theta)}(p, q)}{\sum_{p=0}^{N-1} \sum_{q=0}^{N-1} S_{(d, \theta)}(p, q)}
$$

このようにして得た行列 $\boldsymbol{P}_{(d, \theta)} \in \Re^{N \times N}$ を, 以下に示す式 （2）（6）に代入し， 5 種類の特徵量として, エネルギー, エン トロピー，慣性，相関，局所一様性を算出する.

・エネルギー

$$
E\left(\boldsymbol{P}_{(d, \theta)}\right)=\sum_{p=0}^{N-1} \sum_{q=0}^{N-1}\left\{P_{(d, \theta)}(p, q)\right\}^{2}
$$

・エントロピー

$$
H\left(\boldsymbol{P}_{(d, \theta)}\right)=-\sum_{p=0}^{N-1} \sum_{q=0}^{N-1} P_{(d, \theta)}(p, q) \log P_{(d, \theta)}(p, q)
$$

・慣性

$$
I\left(\boldsymbol{P}_{(d, \theta)}\right)=\sum_{p=0}^{N-1} \sum_{q=0}^{N-1}(p-q)^{2} P_{(d, \theta)}(p, q)
$$

- 相関

$$
C\left(\boldsymbol{P}_{(d, \theta)}\right)=\frac{\sum_{p=0}^{N-1} \sum_{q=0}^{N-1} p q P_{(d, \theta)}(p, q)-E_{x} E_{y}}{D_{x} D_{y}}
$$


- 局所一様性

$$
L\left(\boldsymbol{P}_{(d, \theta)}\right)=\sum_{p=0}^{N-1} \sum_{q=0}^{N-1} \frac{P_{(d, \theta)}(p, q)}{1+(p-q)^{2}}
$$

ただし，式（5）の $E_{x}, E_{y}, D_{x}, D_{y}$ は,

$$
\begin{gathered}
E_{x}=\sum_{p=0}^{N-1}\left\{p \sum_{q=0}^{N-1} P_{(d, \theta)}(p, q)\right\} \\
E_{y}=\sum_{q=0}^{N-1}\left\{q \sum_{p=0}^{N-1} P_{(d, \theta)}(p, q)\right\} \\
D_{x}^{2}=\sum_{p=0}^{N-1}\left\{\left(p-E_{x}\right)^{2} \sum_{j=0}^{N-1} P_{(d, \theta)}(p, q)\right\} \\
D_{y}^{2}=\sum_{q=0}^{N-1}\left\{\left(q-E_{y}\right)^{2} \sum_{i=0}^{N-1} P_{(d, \theta)}(p, q)\right\}
\end{gathered}
$$

である. 以上の計算によって, 各フレームにつき, 濃度共起行列 20 とおり $\times$ 特徵量 5 種類 $=$ 計 100 種類の特徵量を算出する.

Fig. 7 (a) ( e) に, $d=1$ [pixel], $\theta=0$ [deg] の濃度共起行列 $\boldsymbol{P}_{(d, \theta)}$ から算出された 5 種類の特徵量について, フレームごと の変化を示す. なお, その他の $d, \theta$ の場合でも, 各特徴量の 傾向は同様である。これらの特徴量は, 時間に応じて各フレー ムで変化するため, 印象レベル間の違いが顕著に現れているフ レームの特徵量を代表特徵量として採用する. Fig. 7 (a), (c), (e)より, エネルギー, 慣性, 局所一様性は最大值を, Fig. 7 (b), (d)より, エントロピーと相関については最小值を代表特徴量 として採用する. 以上より, 一つの食品の圧力分布応答に対し て, 代表特徴量に破断フェーズのフレーム数を加えた $F=101$ 次元の特徵量べクトル $\boldsymbol{x}=\left[x_{1}, x_{2}, \ldots, x_{F}\right]^{\mathrm{T}} \in \Re^{F}$ を得る.

\section{2 主成分分析による特徵量の絞り込み}

特徵量間での高い相関関係を除去するために主成分分析を施 し, 特徵量ベクトル $\boldsymbol{x}$ の次元を圧縮する. 咀嚼実験から得た 圧力分布応答データの総数を $M$ とし, 圧力分布応答データ $k(k=1,2, \ldots, M)$ から得た特徵量ベクトルを

$$
\boldsymbol{x}_{k}=\left[x_{k 1}, x_{k 2}, \ldots, x_{k F}\right]^{\mathrm{T}} \in \Re^{F}
$$

とする.ただし, 今回の実験では, $M=34$ である. 次式のよ うに, 全特徴量ベクトルを並べた行列 $\boldsymbol{X}$ を作成する.

$$
\boldsymbol{X}=\left[\begin{array}{c}
\boldsymbol{x}_{1}^{\mathrm{T}} \\
\boldsymbol{x}_{2}^{\mathrm{T}} \\
\vdots \\
\boldsymbol{x}_{M}^{\mathrm{T}}
\end{array}\right] \in \Re^{M \times F}
$$

さらに，次式のような列べクトル $\chi_{i} \in \Re^{M}$ を定める.

$$
\boldsymbol{X}=\left[\begin{array}{llll}
\chi_{1} & \chi_{2} & \cdots & \chi_{F}
\end{array}\right] \in \Re^{M \times F}
$$

次に, 行列 $\boldsymbol{X}$ の相関係数行列 $\boldsymbol{R}$ を算出し, 行列 $\boldsymbol{R}$ の固有值 $\lambda_{i}(i=1,2, \ldots, F)$ と大きさ 1 の固有ベクトル $\boldsymbol{u}_{i} \in \Re^{F}$ から 成る行列 $U$ を次式のように算出する.

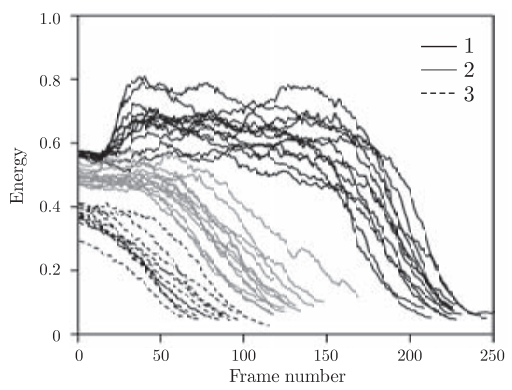

(a)

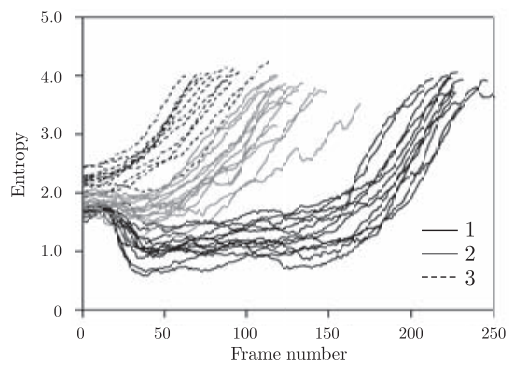

(b)

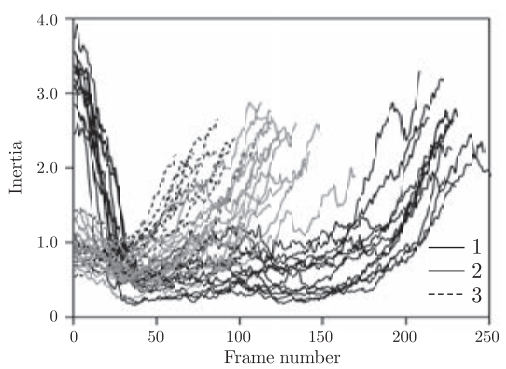

(c)

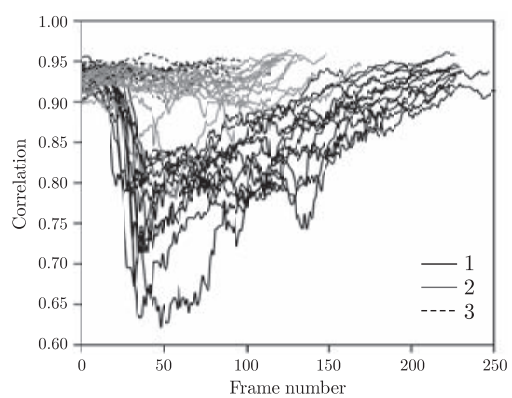

(d)

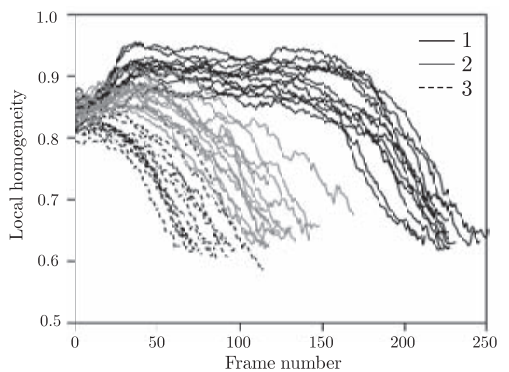

(e)

Fig. 7 An example of feature values with respect to time 


$$
\begin{aligned}
\boldsymbol{R}= & {\left[\begin{array}{cccc}
r_{1,1} & r_{1,2} & \cdots & r_{1, F} \\
r_{2,1} & r_{2,2} & & \vdots \\
\vdots & & \ddots & \vdots \\
r_{F, 1} & \cdots & \cdots & r_{F, F}
\end{array}\right] \in \Re^{F \times F} } \\
= & {\left[\begin{array}{cccc}
\lambda_{1} & 0 & \cdots & 0 \\
0 & \ddots & \ddots & \vdots \\
\vdots & \ddots & \ddots & 0 \\
0 & \cdots & 0 & \lambda_{F}
\end{array}\right] \boldsymbol{U}^{-1} } \\
\boldsymbol{U}= & {\left[\begin{array}{cccc}
\boldsymbol{u}_{1} & \boldsymbol{u}_{2} & \cdots & \boldsymbol{u}_{F}
\end{array}\right] \in \Re^{F \times F} }
\end{aligned}
$$

ただし, $r_{i, j}$ はべクトル $\chi_{i}(i=1, \ldots, F)$ と $\chi_{j}(j=1, \ldots, F)$ の相関係数を表す. 行列 $\boldsymbol{U}$ から, $\lambda_{i} \geq 1$ の固有值に対応する 固有べクトル $\boldsymbol{u}_{i}$ を抽出し, 次式の行列 $U_{\lambda \geq 1} \in \Re^{F \times \mathcal{L}}$ を作成 する。

$$
\boldsymbol{U}_{\lambda \geq 1}=\left[\begin{array}{llll}
\boldsymbol{u}_{(1)} & \boldsymbol{u}_{(2)} & \cdots & \boldsymbol{u}_{(\mathcal{L})}
\end{array}\right] \in \Re^{F \times \mathcal{L}}(17)
$$

ただし， $\mathcal{L}$ は $\lambda_{i} \geq 1$ を満たす固有值の総数であり, $\boldsymbol{u}_{(l)}(l=$ $1,2, \cdots, \mathcal{L})$ は $\lambda_{i} \geq 1$ を満たす固有值に対応する固有べクトル $\boldsymbol{u}_{i}$ である. 次に, 行列 $\boldsymbol{X}$ を構成する $\chi_{i}$ を標準化して, 次の ような行列 $\bar{X}$ を用意する.

$$
\overline{\boldsymbol{X}}=\left[\begin{array}{llll}
\bar{\chi}_{1} & \bar{\chi}_{2} & \cdots & \bar{\chi}_{F}
\end{array}\right] \in \Re^{M \times F}
$$

ただし，

$$
\begin{gathered}
\bar{\chi}_{i}=\left[\bar{\chi}_{i 1}, \bar{\chi}_{i 2}, \ldots, \bar{\chi}_{i M}\right]^{\mathrm{T}} \in \Re^{M} \\
\bar{\chi}_{i k}=\frac{\chi_{i k}-\mu_{i}}{\sigma_{i}} \\
\mu_{i}=\frac{1}{M} \sum_{k=1}^{M} \chi_{i k} \\
\sigma_{i}^{2}=\frac{1}{M} \sum_{k=1}^{M}\left(\mu_{i}-\chi_{i k}\right)^{2}
\end{gathered}
$$

最後に, 主成分ベクトルを構成する行列 $\boldsymbol{Y}$ を次式のように算 出する。

$$
\begin{aligned}
\boldsymbol{Y} & =\overline{\boldsymbol{X}} \boldsymbol{U}_{\lambda \geq 1} \\
& =\left[\begin{array}{c}
\boldsymbol{y}_{1}^{\mathrm{T}} \\
\boldsymbol{y}_{2}^{\mathrm{T}} \\
\vdots \\
\boldsymbol{y}_{M}^{\mathrm{T}}
\end{array}\right] \in \Re^{M \times \mathcal{L}}
\end{aligned}
$$

式 $(24)$ 中の $\boldsymbol{y}_{k}$ が, 圧力分布応答データ $k$ の主成分ベクトル

$$
\boldsymbol{y}_{k}=\left[y_{k 1}, y_{k 2}, \ldots, y_{k \mathcal{L}}\right]^{\mathrm{T}} \in \Re^{\mathcal{L}}
$$

である. なお, 今回の実験データでは, 次元 $\mathcal{L}=4$ である.

\section{3 重回帰分析による印象レベル推定式の導出}

主成分ベクトル $\boldsymbol{y}$ を説明変数, 印象レベル $n$ を目的変数とし て重回帰モデルを作成し, 印象レベルの推定式を獲得する。主 成分ベクトル $\boldsymbol{y}$ と印象レベル $n$ の関係が, 線形回帰式

$$
n=a_{0}+a_{1} y_{1}+a_{2} y_{2}+\cdots+a_{\mathcal{L}} y_{\mathcal{L}}
$$

すなわち，

$$
\begin{gathered}
n=\boldsymbol{a}^{\mathrm{T}}\left[\begin{array}{c}
1 \\
\boldsymbol{y}
\end{array}\right] \\
\boldsymbol{a}=\left[a_{0}, a_{1}, \ldots, a_{\mathcal{L}}\right]^{\mathrm{T}} \in \Re^{\mathcal{L}+1}
\end{gathered}
$$

で与えられるものと仮定する．ただし， $a_{0}$ は定数項， $a_{l}(l=$ $1,2, \ldots, \mathcal{L})$ は各主成分に対する偏回帰係数である.すべての試 験食品デー夕 $n_{k}, \boldsymbol{y}_{k}(k=1,2, \ldots, M)$ に式 $(27)$ を適用し, 次式を得る。

$$
n=Z a
$$

ただし，

$$
\begin{gathered}
\boldsymbol{n}=\left[n_{1}, n_{2}, \ldots, n_{M}\right]^{\mathrm{T}} \in \Re^{M} \\
\boldsymbol{Z}=\left[\begin{array}{cc}
1 & \boldsymbol{y}_{1}^{\mathrm{T}} \\
\vdots & \vdots \\
1 & \boldsymbol{y}_{M}^{\mathrm{T}}
\end{array}\right] \in \Re^{M \times(\mathcal{L}+1)}
\end{gathered}
$$

式 (29) より, 定数項と偏回帰係数の推定值を次式で算出する.

$$
\hat{a}=Z^{\sharp} n
$$

ただし， $\boldsymbol{Z}^{\sharp}=\left(\boldsymbol{Z}^{\mathrm{T}} \boldsymbol{Z}\right)^{-1} \boldsymbol{Z}^{\mathrm{T}}$ は $\boldsymbol{Z}$ の擬似逆行列である. 以上 の手順により, 圧力分布応答データ $k$ から得た主成分ベクトル $\boldsymbol{y}_{k}$ に対する印象レベルの推定式

$$
\hat{n}_{k}=\hat{\boldsymbol{a}}^{\mathrm{T}}\left[\begin{array}{c}
1 \\
\boldsymbol{y}_{k}
\end{array}\right]
$$

を得る. なお, 定数項および偏回帰係数 $a_{l}=0$ の帰無仮説に ついて検定を行い, 危険率 $5 \%$ 以上の定数項あるいは偏回帰係 数項が存在する場合はこれらを除去して, 再度重回帰分析を行 う.この作業を, すべての定数項および偏回帰係数の危険率が $5 \%$ 以下になるまで繰り返し, 最終的な印象レベルの推定式を決 定する. Fig. 8 に, 推定された印象レベルと実際の印象レベル の関係を示す. 決定係数は $R^{2}=0.95$, 推定值 $\hat{n}$ の標準誤差は 0.19 であり, 十分精度の良い推定結果が得られている。とりわ け, Fig. 6 に示したような力応答に基づく従来のテクスチャプ ロファイル法では判別困難な $n=2$ と $n=3$ のゼリーについ ても, 提案手法では両者の違いを明快に判別可能であることを 強調しておきたい. これは, 食品テクスチャを評価するために, ゼリー破断中の幾何学的情報として圧力分布答を活用し, 幾何 学的な相違が印象レベルに与える影響を適切にモデル化できた 効果が発揮されたためと考えている. 
東森充金子

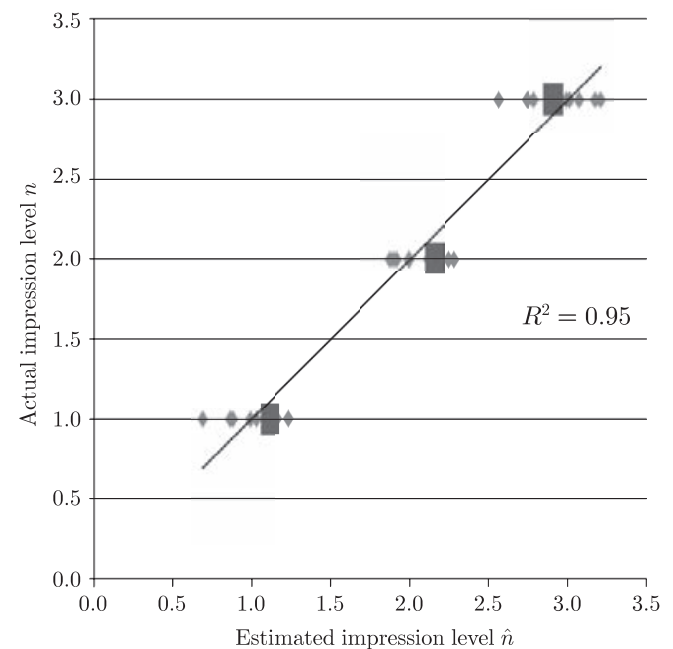

Fig. 8 Relationship between estimated and actual impression levels between 1,2 , and 3

\section{4 未知食品の印象レベル推定}

未知食品の圧力分布応答を計測し, 4.1 節の手順で特徵量べ クトル $\boldsymbol{x}_{*}=\left[x_{* 1}, x_{* 2}, \ldots, x_{* F}\right]^{\mathrm{T}} \in \Re^{F}$ を算出する. この特徵 量ベクトル $\boldsymbol{x}_{*}$ を, 式（21）（22）を用いて次式のように標準化 する。

$$
\begin{gathered}
\overline{\boldsymbol{x}}_{*}=\left[\bar{x}_{* 1}, \bar{x}_{* 2}, \ldots, \bar{x}_{* F}\right]^{\mathrm{T}} \in \Re^{F} \\
\bar{x}_{* i}=\frac{x_{* i}-\mu_{i}}{\sigma_{i}}
\end{gathered}
$$

標準化ベクトル $\overline{\boldsymbol{x}}_{*}$ を用いて, 次式のように未知食品の主成分 ベクトル $\boldsymbol{y}_{*}$ を算出する.

$$
\boldsymbol{y}_{*}=\left[\overline{\boldsymbol{x}}_{*}^{\mathrm{T}} \boldsymbol{U}_{\lambda \geq 1}\right]^{\mathrm{T}} \in \Re^{\mathcal{L}}
$$

式（33）に準拠し, 未知食品の印象レベルを次の推定式で算出 する.

$$
\hat{n}_{*}=\hat{\boldsymbol{a}}^{\mathrm{T}}\left[\begin{array}{c}
1 \\
\boldsymbol{y}_{*}
\end{array}\right]
$$

$\hat{a}$ の算出に使用していない, すなわち, 圧力分布応答と印象レ ベルのモデル化に用いていない基準食品のゼリー 3 個（それぞ れ実際の印象レベルが $n=1 ， 2 ， 3 ）$ を未知食品とみなし，印 象レベルを推定した結果を, Fig. 8 にプロットロで示す.この 結果から, 今回使用した基準食品については, 提案手法によっ て印象レベルを的確に推定可能であることが確認できる.

Fig.9(a)は, Fig. 8 から実際の印象レベルが $n=\{2,3\}$ のゼリーの推定結果を取り出したものを示している. Fig. 8 に 示すように, 印象レベル $n=\{1,2,3\}$ に対する決定係数が $R^{2}=0.95$ であるのに対して, Fig. 9 (a) に示すように, 印象 レベル $n=\{2,3\}$ に対する決定係数は $R^{2}=0.86$ と低下し ている. これは, $n=2$ と $n=3$ のゼリーに関する識別精度 が, $n=1$ と両者の識別精度よりも劣ることを意味しており, Fig. 5 (b), (c) の圧力分布応答の類似性からも直感的に理解で きる.これに対して, Fig. 9(b) に, 印象レベル $n=\{2,3\}$ の データのみでモデル化を行い, 印象レベルを推定した結果を示
真福田修

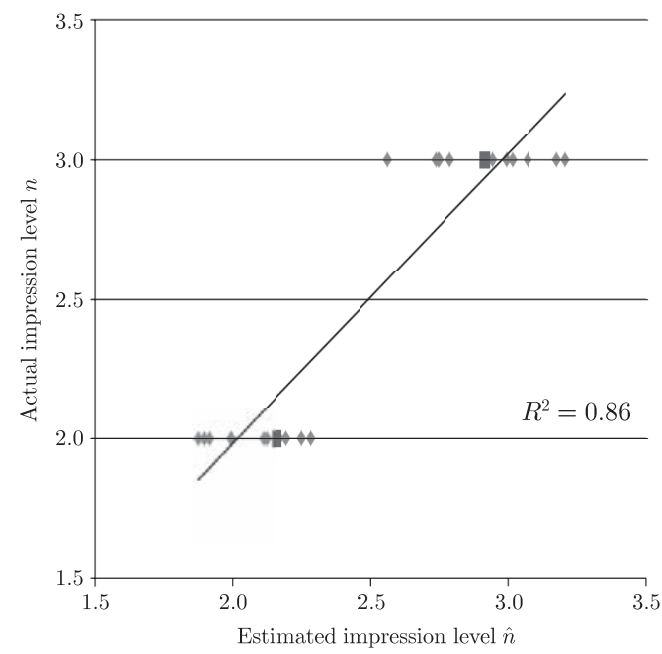

(a)

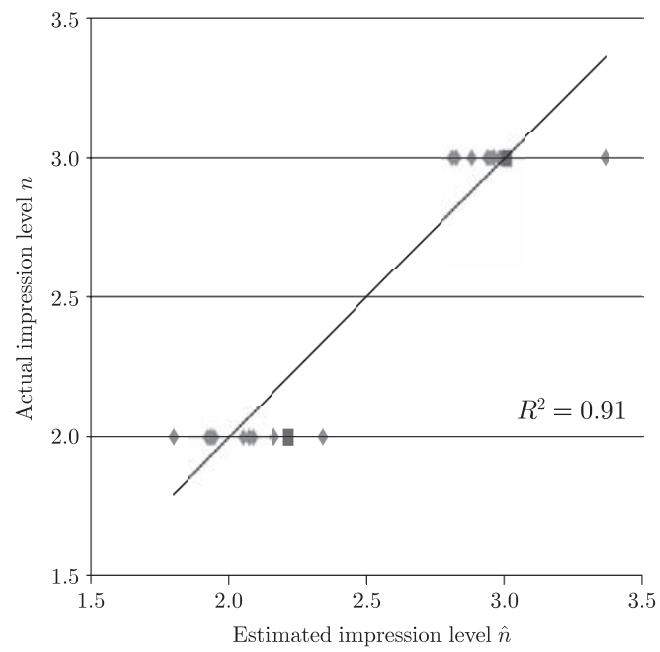

(b)

Fig. 9 Relationship between estimated and actual impression levels between 2 and 3

す.このとき, 決定係数は $R^{2}=0.91$ となり, Fig. 9(a)の場 合と比較して, 推定精度が向上していることが分かる。 これは, 推定対象とする印象レベルを $n=\{2,3\}$ に絞ることにより, 主 成分ベクトル内に执いて両者を区別するための情報量の割合が 増加したためと想定される. 以上の結果から, 推定精度の悪い 印象レベル間でローカルなモデル化をするような階層化処理が 精度向上のために有効といえる.

\section{5. 結論}

本研究では, 咀嚼時の圧力分布応答に基づく食品テクスチャ センシング手法を提案した，具体的には，ヒトの官能評価に基 づく食品テクスチャの印象レベルと咀嚼実験モデルで得られる 食品破断中の圧力分布応答との関係をモデル化した．ここでは, 圧力分布応答デー夕に画像テクスチャ解析手法を適用して特徵 量を算出し, 主成分分析および重回帰分析によって, 印象レベ ルの推定式を導出した，今回，舌触りが明確に異なる 3 種類の ゼリーを用いた基礎実験により, 提案手法によって印象レベル 
が精度よく推定できることを示した。 また，モデル化に使用し ていないゼリーの印象レベルが適切に推定できることを示した．

現状, 食品テクスチャセンシング手法の基本コンセプト提案 し，介護食ゼリー 3 種を取り上げて実現性の見通しが確認でき た段階と考えている. 今後, 実応用に向けて, 咀嚼動作（単純 圧縮だけでなく, 正弦波等の繰り返し圧縮など), 圧力分布応答 の特徵量（空間的だけでなく，時間相関などの時間的な特徵量）, 官能評価指標と圧力分布応答のモデリング（線形 $\rightarrow$ 非線形）の バリエーションを十分に検証していかなければならない.とり わけ，ヒトが咀嚼時に感じる印象群のうち，どのような印象を どのような範囲と精度で本手法により感知するかといった見極 めが, 提案手法による食感評価の信頼性向上のための重要なポ イントとなると考えている。一方で，本論文では舌式咀嚼およ び介護食ゼリーに対象を絞って議論したが，提案手法は一般的 な歯を用いた咀嚼および健常者向け食品にも拡張可能であるこ とに留意されたい. 今後, 実食品を用いた実験を通じて検証を 深め, 将来的には, 高齢者や障害者にとどまらず，健常者ある いは乳幼児の摂食も視野に入れた食感自動評価システムの開発 を試みたい。

謝 辞 本研究は, 平成 24 年度公益財団法人日本食品化学 研究振興財団研究助成「破断中の圧力分布応答に基づく新しい テクスチャー評価手法の構築」の支援を受けて行われた。 また,
現東京大学大学院生黒瀬優介君, 大阪大学大学院生柴田暁秀君, 山本武君には実験およびデー夕解析に多大に協力いただいた。 心より感謝の意を表す。

\section{参 考 文 献}

[1] 磯直道, 水野治夫, 小川廣男：食品のレオロジー一食の物性評価一 成山堂書店, 1998 .

[2 $]$ A.S. Szczesniak: "Classification of Textural Characteristics," Journal Food Science, vol.28, pp.285-289, 1963.

[ 3 ] M.C. Bourne: "Texture Profile Analysis," Food Technology, vol.32, no.72, pp.62-66, 1978.

[4] 群馬県立産業技術センター, http://mac.tec-lab.pref.gunma.jp/ dt0319.html

[ 5 ] 英弘精機株式会社, http://www.eko.co.jp/eko/index.html

[6] S. Ishihara, M. Nakauma, T. Funami, S. Odake and K. Nishinari: "Viscoelastic and Fragmentation Characters of Model Bolus from Polysaccharide Gels after Instrumental Mastication," Food Hydrocolloids, vol.25, pp.1210-1218, 2011.

[ 7 ] 今井悦子, 田丸理恵, 烟江敬子, 島田淳子： “口腔に打ける粒子の認識 と粒度の識別におよぼす食品物性の影響”, 日本家政学会誌, vol.49, no.3, pp.243-253, 1998.

[8] 神山かおる：“新しい食品テクスチャー計測の試み”, 食糧：その科 学と技術, vol.38, pp.85-102, 1999.

[9] 神山か扔る：“多点計測による食品テクスチャーの評価”, 日本食品科 学工学会誌, vol.52, no.2, pp.45-51, 2005.

[10] 田村秀行：コンピュータ画像処理. オーム社, 2002.

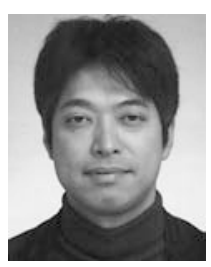

東森 充 (Mitsuru Higashimori)

1998 年広島大学大学院工学研究科博士課程前期修 了. 同年株式会社東芝入社. 2002 年広島大学大学 院工学研究科助手, 2006 年大阪大学大学院工学研 究科助手, 2008 年同准教授, 現在に至る. 博士 (工 学)、ロボットによる操り技術, 柔軟物体のセンシ ング・ハンドリングに関する研究に従事. 計測自動 制御学会, 日本機械学会, 日本生体医工学会, IEEE の会員.

(日本ロボット学会正会員)

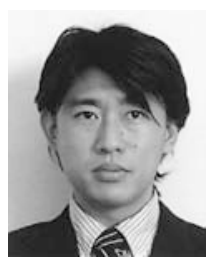

福田 修 (Osamu Fukuda)

2000 年広島大学大学院工学研究科博士課程後期修 了. 1997 年 2000 年の期間, 日本学術振興会特別 研究員 (DC1). 2000 年通商産業省工業技術院機械 技術研究所入所, 2001 年独立行政法人産業技術総 合研究所へ転任. 2004 年より広島大学大学院工学 研究科客員准教授. 2010 年より同教授, 現在に至 る。博士 (工学)。ヒューマンインタフェース, 超音波センシングな どの研究に従事. 計測自動制御学会, 日本機械学会, IEEE の会員.

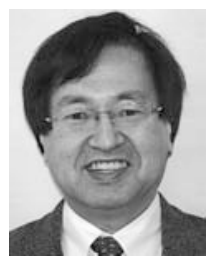

\section{金子 真 (Makoto Kaneko)}

1981 年東京大学工学系研究科博士課程卒業. 工学 博士。通産省工業技術院機械技術研究所, 九州工 業大学助教授, 広島大学教授を経て, 2006 年より 大阪大学教授, 現在に至る. 現在は, 赤血球の高速 硬さ計測，脳波，眼の硬さ計測，セルマニピュレー ションに関する研究に従事. 日本機械学会奨励賞 (1983), 日本ロボット学会論文賞 (1994，2007), 計測自動制御学会 論文賞 $(1996,2002 ， 2008 ， 2010)$, 日本コンピュータ外科学会講 演論文賞最優秀賞 (2004), IEEE RAS Best Tans. Paper Award （2003）などを受賞. 